\title{
KOŚCIELNE FUNDACJE JANA DŁUGOSZA
}

Współczesny Janowi Długoszowi biograf zanotował o naszym dziejopisie te słowa: ,nam quantum a cupiditate pecuniae abfuerit, testantur aedificia, vestes, tabulae, vasa, picturae, libri, qua partim exornatis, partim instauratis, partim ex integro aedificatis ecclesiis plurimis in locis ipso auctore pulcherrima et pretiosa visuntur" 1.

Jan Długosz należał do najwybitniejszych postaci polskiego życia kulturalnego u schyłku średniowiecza. Związany bez przerwy. z Krakowem, wychowawca synów królewskich, znakomity gospodarz i dyplomata ${ }^{2}$, był także wybitnym fundatorem licznych dzieł sztuki rozproszonych po całej Małopolsce ${ }^{3}$. Jego fundatorska działalność na rzecz Kościoła nie posiada analogii w kulturze artystycznej XV stulecia. Nie ma najmniejszej przesady w twierdzeniu, że poczynania budowlane i fundacyjne stały się obok pracy historycznej pasją życiową Długosza. Wpływał przy tym - co należało do rzadkości — na jakość sprawianych dzieł sztuki. Opatrywał je zawsze tablicą erekcyjną, umieszczoną na widocznym miejscu i zawierającą jeśli nie jego imię, to przynajmniej herb Wieniawa, który także wielokrotnie powtórzony ozdabiał fundowany obiekt ${ }^{4}$. Długosz przyczynił się do wzniesienia wielu budowli, głównie sakralnych, w tym kościołów parafialnych oraz zakonnych. Szczególną opieką otoczył świątynie na terenie rozległej wówczas diecezji krakow-

I Vita Joannis Dlugosch senioris, canonici Cracovienis. Ed. M. Brożek, Varsosoviae 1961, s. 36-37. Przypuszcza się, że autorem tego życiorysu był Filip Kallimach; por. M. Brożek, Czy Filip Kallimach jest autorem Żywotu Długosza?, ]w:[ Zeszyty Naukowe Uniwersytetu Jagiellońskiego 21, Prace Historyczno-Literackie z. 3, Kraków, s. $11-60$.

2 F. Papée, Dlugosz Jan (1415-1480), [w:] PSB V, s. 176-180; J. Dąbrowski, Dawne dziejopisarstwo polskie (do roku 1480), Wrocław-Warszawa-Kraków 1964, s. 189-240. O związkach Długosza z Krakowem: por. K. Pieradzka, Zwiazki Długosza z Krakowem, Kraków 1975.

3 W. Euszczkiewicz, Budowle Dtugosza. „Kłosy” 31 (1880) nr 786-787, s. 60-61, 77-78; I. Polkowski, Budowle Dtugosza. „Kłosy” 30 (1880) nr 777, s. 326-330; M. Bobrzyński, S. Smolka, Jan Długosz. Jego życie i stanowisko w piśmiennictwie, Kraków 1893, s. 198-215; J. Smoleńska, Działalność budowlana Jana Długosza. „Kwartalnik Architektury i Urbanistyki” 14 .(1969) s. 161-178.

4 S. K. Kuczyński, Herby w twórczości historycznej Jana Długosza, [w:] Sztuka i ideologia XV wieku, pod red. P. Skubiszewskiego, Warszawa 1978, s. 226-227. 
skiej, budując nowe kościoły i opatrując je "wykwintnymi aparatami liturgicznymi.

Bazą ekonomiczną Długoszowych fundacji był znaczny majątek, uzyskany z tytułu piastowanych godności kościelnych. Swoją karierę rozpoczął Długosz na dworze wszechwładnego biskupa krakowskiego Zbigniewa Oleśnickiego. Dostał się tam w szesnastym roku życia. Najpierw został notariuszem, potem sekretarzem, wreszcie kanclerzem, a z upływem czasu bliskim powiernikiem tego wybitnego dostojnika. W kancelarii biskupiej szyblko dał się poznać wyśmienity talent i zmysł gospodarczy młodego Długosza. Dobrze zarządzał dobrami biskupstwa krakowskiego, spisywał inwentarze, gromadził odpowiednie dokumenty dotyczące prawa własności, co później wykorzystał przy pisaniu Liber beneficiorum dioecesis Cracoviensis. Nauczył się tėz zasady, że grosz oszczędzony należy zawsze obrócić dla dobra innych. Biskup krakowski szybko docenił zalety swego podopiecznego. Posypały się zaszczyty kościelne. Niebawem Długosz został kanonikiem krakowskim (1436), kustoszem wiślickim 1444), kanonikiem sandomierskim (1456), kanonikiem gnieźnieńskim (1471). Do roku 1449 pełnił też obowiązki proboszcza w Kłobucku. Nadto piastował godność kanonika kolegiaty kieleckiej. Funkcje te zapewniały Długoszowi spory majątek i stałe dochody czerpane z licznych beneficjów. Kanonia krakowska dawała mu początkowo rocznego dochodu 20 grzywien, potem dochody podniosły się do 30 grzywien i dziesięciny z jedenastu wsi. Ponadto, jako kanonik krakowski, dostał od kapituły w dzierżawę wsie Borek Fałęcki, Brzezie, Dziekanowice, Raciborowice, Rudawę, Wyciąże, Węgrzce i Pychowice. Tytułem posiadania kanonii sandomierskiej trzymał wieś Odechów, nadto dziesięciny z Szydłowa, które rocznie przysparzały 7 grzywien dochodu. Kustodia wiślicka dawała Długoszowi dzierżawę Chotla Czerwonego, dziesięciny z siedmiu wsi, co w sumie przynosiło w rozliczeniu rocznym 20 grzywien. Kanonia kielecka dawała także niezgorszy dochód płynący z dzierżawy Szydłówka i dziesięciny z dziesięciu wsi ${ }^{5}$. Należał więc wówczas do zamożniejszych ludzi. Uzyskane pieniądze obracał przede wszystkim na cele fundacyjne, w szczególności budowlano-artystyczne. Stworzył przy tym własną strycharnię i strzechę budowlaną wraz z zapleczem gospodarczym ${ }^{6}$. Powstało swoistego typu przedsiębiorstwo, które pracowało wyłącznie na zlecenie Długosza. Korzystał także z usług licznych krakowskich rzemieślników, co w znacznym stopniu ułatwiało mu realizację podjętych zamierzeń fundacyjnych ${ }^{7}$. W tej dziedzinie mógł śmiało rywalizować $\mathrm{z}$ królem oraz najbliższym otoczeniem monarchy ${ }^{8}$.

5 Dane według: M. Bobrzyński, S. Smolka, jw., s. 198-199.

6 Wypisy źródłowe do dziejów Wawelu 1440-1500. Opr. B. Przybyszewski, Kraków 1960, nr 82, 89, 100; J. Smoleńska, jw., s. 169.

7 T. Dobrowolski, Życie, twórczość $i$ znaczenie spoleczne artystów polskich $i w$ Polsce pracujących w okresie późnego gotyku (1440-1520), Wrocław-Warszawa-Kraków 1965.

8 M. Bobrzyński, S. Smolka, jw., s. 198; Historia sztuki polskiej, pod red. T. Dobrowolskiego, t. 1, Kraków 1965, s. 196. 
Większość fundacji kościelnych zrealizował Długosz w dwóch zasadniczych etapach: 1450 - 1460 i 1470 - 1480. Okres pomiędzy rokiem 1460 a 1470 wiąże się z pewnym osłabieniem aktywności Długosza, związa-nym przynajmniej w latach $1460-1463 \mathrm{z}$ walką o obsadę stolicy biskupiej w Krakowie. Kronikarz poparł papieskiego kandydata Jakuba z Sienna, który pozostawał w opozycji do Kazimierza Jagiellończyka. Król obłożył banicją zwolenników Jakuba z Sienna, wśród których znalazł się Długosz. Stracił swój dom w Krakowie i przez kilka lat tułał się przy boku Jakuba, którego uważał za prawego biskupa, posiadającego nominację papieską. Konflikt zakończył się kompromisem: Jakub zrezygnowal $z$ biskupstwa krakowskiego (niebawem otrzymał diecezję włocławską) i wraz ze swymi zwolennikami został dopuszczony do laski królewskiej ${ }^{9}$. Niebawem król Kazimierz powierzył Długoszowi edukację swoich synów. Stało się to w roku 1467. Doszły zatem nowe obowiązki. Nie zaniedbał jednak działalności fundacyjnej, którą znakomicie rozwinął w ostatnim ḋziesięcioleciu swego życia.

Pierwszą większą fundacją Dlugosza był kościół w Chotlu Czerwonym, położonym $\mathrm{w}$ pobliżu Wiślicy ${ }^{10}$. W roku 1450 przyśstąpił Długosz do budowy nowego kościoła. Zburzono stary drewniany i wzniesiono ceglaną świątynię pod wezwaniem św. Stefana. Fundator hojnie ją uposażył, a także ,vitris et casulis et calicibus et imaginibus aliisque clenodiis adornavit" "11. Kościół zlokalizowany został na wyniosłym wzgórzu. Wykonany $\mathrm{z}$ kamienia i cegły, składa się $\mathrm{z}$ kwadratowej nawy oraz podobnego prezbiterium, nieco węższego od nawy. Od południa do nawy przylega gotycka kruchta. Sklepienia krzyżowo-żebrowe, nakrywające prezbiterium, nawę i kruchtę, zdobią zworniki z herbami: w prezbiterium Orzeł, w nawie i kruchcie Wieniawa oraz Dębno (kardynała Zbigniewa Oleśnickiego). Dekorację uzupełnia kamienna tablica erekcyjna wyobrażająca płaskorzeźbione postacie Madonny w otoczeniu śś. Hieronima i Stefana. Okala ją obramienie wypełnione inskrypcją, uwzględniającą $w$ tekście datę fundacji, pomijającą jednak osobę fundatora ${ }^{12}$.

Drugim przedsięwzięciem fundacyjnym Długosza był kościół w Kłobucku. Z parafią kłobucką łączyły go liczne związki, bowiem od drugiego dziesięciolecia XV w. kościół w Kłobucku obsadzony był przez rodzinę

9 F. Papée, s. 177; F. Kiryk, Jakub z Sienna (1413-1480), [w:] PSB IX, s. $364-$ $-367$.

10 Katalog zabytków sztuki w Polsce, t. 3, Warszawa 1961, z. 9, s. 9-10; J. Wiśniewski, Historyczny opis kościołów, miast zabytków i pamiątek $w$ pińczowskiem, skalbmierskiem $i$ wiślickiem, Marjówka 1927, s. 78-83.

11 Liber beneficiorum I, s. 417 n., II, s. 372. Por. komunikat M. Wawrzenieckiego [w:] Sprawozdania Komisji do Badania Historii Sztuki w Polsce, t. 8, Kraków 1912, szp. CCLVI.

12 Tekst tablicy podaje I. Polkowski (jw., s. 326). 
Długoszów. W roku 1410 Władysław Jagiełło dał probostwo kłobuckie Bartłomiejowi Długoszowi, stryjowi naszego dziejopisa. Warto nadmienić, że Bartłomiej uczestniczył w bitwie grunwaldzkiej, pełniąc obowiązki królewskiego kapelana. Kiedy 31 października 1434 Bartłomiej zrezygnował $\mathrm{z}$ probostwa, cedując go na rzecz bratanka Jana seniora, ten $\mathrm{z}$ kolei w roku 1449 oddał parafię swemu bratu Janowi, zwanemu juniorem. Pięć lat później przekonał brata do zrzeczenia się tego probostwa i po uzyskaniu przywileju królewskiego sprowadził do Kłobucka kanoników laterańskich, podporządkowując ich krakowskiej kongregacji mieszczącej się przy kościele Bożego Ciała na Kazimierzu ${ }^{13}$. Uprzednio Długosz uzyskał od kardynała Oleśnickiego przywilej potwierdzający uposażenia i dochody probostwa kłobuckiego ${ }^{14}$. Dobra baza materialna stała się podstawą działalności kanoników laterańskich w Kłobucku. Pierwszym przełożonym nowego konwentu został brat Filip $z$ Krakowa ${ }^{15}$. Długosz wspomina o fundacji Kłobucka, nic jednak nie pisze o budowie klasztoru i nowego kościoła. Znajdujące się w kościele detale architektoniczne (portal wiodący z prezbiterium do zakrystii, okna $\mathrm{w}$ prezbiterium) formalnie wykazują zbieżne cechy $\mathrm{z}$ innymi fundacjami budowlanymi Długosza ${ }^{16}$. Pozwalają zatem na związanie budowy kościoła kłobuckiego z imieniem naszego dziejopisa. Zapewne wkrótce po sprowadzeniu pierwszych zakonników przystąpiono do wzniesienia przynajmniej prowizorycznego drewnianego klasztoru, natomiast większe przedsięwzięcie architektoniczne, zainicjowane przez Długosza u schyłku życia, ukończono przypuszczalnie już po jego śmierci, skoro $\mathrm{w}$ Líber beneficiorum brakuje jakichkolwiek wzmianek o budowlach w Kłobucku. Jednak mimo tych niejasności wiele istotnego materiału wnoszą wzmianki archiwalne dotyczące Kłobucka, przechowywane obecnie w zbiorach Biblioteki PAN w Krakowie. Prace przy budowie wzmiankowane są w rachunkach klasztoru kłobuckiego w latach 1466, 1473, 1477, 1479. Pożar, który strawił miasto w roku 1469, nieznacznie zniszczył kościół, a straty szybko usunięto. Na rok 1477 przypadło nasilenie prac organizacyjnych związanych z budową. Długosz sprowadził wtedy robotników i postawił cegielnię. W roku 1479 w obecności Długosza założono fun-

13 O kościele w Kłobucku por.: Katalog zabytków sztuki w Polsce, t. 6, Warszawa 1963, z. 7, s. 10-17; Z. Perzanowski, Zarys dziejów miasta Kłobucka. „Małopolskie Studia Historyczne" 1 (1958), z. 2, s. 33-34; W. Górzyński, Ornat Dtugosza, [w:] Sprawozdania Komisji do Badania Historii Sztuki w Polsce, t. 8, Kraków 1912, szp. CCIII-CCV; T. Kruszyński, Jak pięćset lat temu ks. Jan Dtugosz otrzymai probostwo w Ktobucku. „Kurier Literacko-Naukowy” 12 (1935) nr 10; komunikat M. Witanowskiego [w:] Sprawozdania Komisji do Badania Historii Sztuki $w$ Polsce, t. 9, Kraków 1915, szp. XCIV-XCVI.

14 Kodeks dyplomatyczny Małopolski. Wyd. F. Piekosiński. T. 4, Kraków 1905, s. $486-488$.

15 M. Bobrzyński, S. Smolka, jw., s. 202; T. Gliński, Kanonicy Regularni (Bożociołki) w opinii Długosza, [w:] Studia z dziejów kościoła Bożego Ciała w Krakowie, pod red. Z. Jakubowskiego, Kraków 1977, s. 195-196.

${ }_{16}$ Katalog zabytków sztuki w Polsce, t. 6 (jw.). W skarbcu kościelnym jest gotycki kielich z herbem Wieniawa, związany z Dlugoszem. 
damenty kościoła. Od stycznia roku 1480 budową kierował murator Jan, który przypuszczalnie już po śmierci kronikarza ukończył kościół ${ }^{17}$. Z osobą Jana Długosza wiąże się ornat przechowywany w kościele kłobuckim, ozdobiony herbem Wieniawa odnoszącym się do fundatora. Wyobraża w pośrodku krzyżowej preteksty symbol ofiary eucharystycznej Ukrzyżowanego Chrystusa z NMPanną i św. Janem Ewangelistą stojącymi pod krzyżem. W zakończeniu ramion preteksty widnieją postacie Ojców Kościoła śś. Hieronima, Grzegorza Wielkiego i Ambrożego, a zatem tych, którzy wiarę i tradycję apostolską przekazali, zinterpretowali, kładąc podwaliny nauki Kościoła. Na przedniej kolumnie wyobrażono od góry Długoszowego patrona św. Jana Chrzciciela oraz prekursora wspólnot życia kanonicznego św. Augustyna i herb Wieniawa. Boki ornatu wykonano z ciemnostrzyżonego aksamitu. Całość należy do piękniejszych haftów figuralnych $z$ epoki gotyku, a jego wartość polega głównie na dobrym rysunku i subtelnej robocie ${ }^{18}$.

Kolejną fundacją Jana Długosza był kościół parafialny w Odechowie. Dobra odechowskie otrzymał jako beneficium w latach 1456-1463. Kościół pod wezwaniem Zwiastowania NMPanny wzniósł Długosz w latach 1459-1460. Zbudowany z cegły, został założony na rzucie prostokąta z węższym prezbiterium, zamkniętym prostą ścianą. Całość założenia opinają mocne skarpy. W latach 1911-1913 świątynię poszerzono wedle projektu Zygmunta Słonimskiego, zatracając w trakcie przebudowy pierwotny kształt przestrzenny z czasów Długosza ${ }^{19}$.

$\mathrm{Na}$ rok 1470 przypada fundacja nowego kościoła w Szczepanowie, miejscu narodzin św. Stanisława, do którego Długosz żywił szczególny kult. Swiątynię pod wezwaniem śś. Stanisława i Marii Magdaleny postawiono na miejscu weześniejszej drewnianej budowli. Kościół pochodzący z fundacji Długosza wykonany został z cegły z detalami kamiennymi. Ma kształt prostokąta z nieco węższym sklepionym krzyżowo prezbiterium, zamkniętym wielobocznie, oraz kruchtą umieszczoną od południa. Do nawy i kruchty prowadzi schodkowy portal, tak charakterystyczny dla budynków wiązanych z osobą Długosza. Na zwornikach

17 Perzanowski, jw., s. 33-34; J. Smoleńska, jw., s. 166. Symbolikę rozwiązano wg: M. Nowodworski, Encyklopedia kościelna, t. 9, Warszawa 1876, s. 451 nn., t. 17 (1891), s. 190 nn.; Lexikon für Theologie und Kirche, t. 5, Freiburg 1960, szp. 1287-1288, t. 8 (1963), szp. 183-187.

18 W. Górzyński, jw., szp. CCV; A. Bochnak, J. Pagaczewski, Polskie rzemiosio artystyczne wieków średnich, Kraków 1959, s. 216-218; Polskie hafty średniowieczne. Katalog wystawy maj-czerwiec 1967, Kraków 1967, s. 30-31.

19 Liber beneficiorum I, s. 344, II, s. 525; J. Wiśniewski, Dekanat radomski, Radom 19 11,s. 162-163; Katalog zabytków sztuki w Polsce, t. 3, Warszawa 1961, z. 10, s. 15-16; J. Smoleńska, jw., s. 162, Zdaniem J. Wiśniewskiego (jw., s. 163) w Domku Gotyckim w Puławach znajdował się ołtarzyk kamienny z kościoła odechowskiego z napisem: „Fabricavit ecclesiam MCCCCLX Johannes Dlugos,.. Z Żgulski podaje, że w Domku Gotyckim wmurowano w ścianę fragment ołtarza (płyty) $\mathrm{z}$ głową Chrystusa, pochodzący z kościoła w Odechowie (Z. Żygulski, Dzieje zbiorów puławskich, w: Rozprawy i Sprawozdania Muzéum Narodowego w Krakowie, t. 7, Kraków 1962, s. 154; por. też I. Czartoryska, Poczet pamiątek zachowanych w Domu Gotyckim w Pulawach, Warszawa 1828, s. 7; J. Powidzki, Zbiory Domu Gotyckiego w Puławach. ,Muzealnictwo” 3, 1956, s. 11). 
sklepiennych w prezbiterium widni ją herby: Orzeł - Królestwa Polskiego, Dębno - kardynała Zbigniewa Oleśnickiego i Leliwa - rodziny Melsztyńskich. Na wspornikach odpowiadają im herby Wieniawa. Nawę nakryto stropem drewnianym. Herb Długosza odnajdujemy także na fasadzie kościoła. Umieszczono go tam powyżej wejścia. Najważniejszą częścią dekoracji architektonicznej świątyni jest kwadratowa kamienna płyta erekcyjna ongiś znajdująca się w kruchcie. Wyobraża św. Stanisława w stroju pontyfikalnym z herbami Dębno i Leliwa, umieszczonymi u stóp patroná Królestwa. Całość okala łaciński napis z datą 1470, uzupełniony w narożach dwoma herbami: Prus (św. Stanisława) i Wieniawą. Kościół w Szczepanowie wyposażył Długosz w liczne aparaty liturgiczne ${ }^{20}$.

Z kultem św. Stanisława wiąże się również fundacja dòtyczącà Skałki. Długosz widząc liczne zaniedbania około sìużby Bożej w miejscu męczeńskiej śmierci św. Stanisława postanowił stojący tưtaj kościół parafialny przekształcić na klasztorny. Zakonnicy gwarantowali stałe odprawianie mszy św. i nabożeństw, wreszcie opiekę nad jeszcze jednym miejscem związanym z kultem głównego patrona Polski. Po uzyskaniu od króla aprobaty dla swego zamiaru oraz zgody biskupa Jana Rzeszowskiego (1471) Długosz sprowadził na Skałkę zakon paulinów z Jasnej Góry. Wydarzenie to odnotował w swojej kronice pod datą 22 czerwca 1472: „,po wynagrodzeniu plebana tegoż kościoła Jana Szebienia dwiema dość korzystnemi prebendami, to jest sandomirską i kielecką [...] ufundował [Długosz] klasztor braci pustelniczych św. Pawła" 21. Zapewne w związku z fundacją przystąpiono do przebudowy kościoła wzniesionego przez Kazimierza Wielkiego ${ }^{22}$, nadto musiano pomyśleć o budowie budynków klasztornych i odpowiedniego zaplecza gospodarczego. Z tego okresu - przynajmniej na obecnym etapie badań - nic się nie zachowało, tak więc zakres prac, jak i koncepcja przestrzenna Skałki z okresu Długosza pozostaje nadal niejasna. Długosz zadbał przypuszczalnie o odpowiednie wykończenie kościoła, skoro na Skałce został pogrzebany ${ }^{23}$.

Ostatnią zrealizowaną w pełni sakralną fundacją Długosza jest kościół parafialny pod wezwaniem św. Małgorzaty w Raciborowicach koło Krakowa. Wieś ta należała do kapituły krakowskiej. Długosz otrzymał ją po kanoniku Pawle z Zatora (zm. 1463). Jeszcze za życia Pawła z Zatora rozpoczęto budowę kościoła. Wtedy powstało prezbiterium (bez skle-

20 Liber beneficorum II, S. 268; W. Euszczkiewicz, Zabytki dawnego budownictwa w krakowskiem, Kraków 1868, z. 5; Katalog zabytków sztuki w Polsce, t. 1, Warszawa 1953, s. 85-86; I. Polkowski, jw., s. 327; M. Bobrzyński, S. Smolka, jw., s. 206; Rocznik diecezji tarnowskiej na rok 1972, Tarnów 1971, s. $137-139$. 21 Jana Dtugosza dzisjów polskich ksiag dwanaście, t. 5, Kraków 1870, s. 540. Por. Vita Joannis Dlugosch, jw., s. 41; Liber beneficiorum III, s. 114-115; L. Zarewicz, Skałka z kościotem śs. Michała $i$ Stanisława $w$ Krakowie, Kraków 1889, s. 35-38; J. Muczkowski, Skałka, Kraków 1897, s. 16-17.

22 Jana Diugosza dziejów polskich..., jw., t. 4, s. 302; L. Zarewicz, jw., s. $28,41$.

23 Por. Zarewicz, jw., s. 42; W. Zin, W. Grabski, Skałka w świetle badań architektonicznych, [w:] Sprawozdania z posiedzeń komisji naukowych PAN - Oddział $w$ Krakowie, t. 11/2, Kraków, 1968, s. 846-848. 
pienia) oraz zakrystia. W takim stanie przejął Długosz budujący się kościół i dokończył rozpoczętego dzieła. Za rządów Długosza powstała prostokątna nawa, zasklepił krzyżowo dwuprzęsłowe prezbiterium oraz zakrystię, nadto od strony południowej dobudował niewielką kruchtę, a w nawie położył drewniany strop. Wtedy też wzniesiono dzwonnicę, w dolnej części murowạną, zaś w górnej drewnianą o konstrukcji słupowej. Całość prac budowlanych ukończono w roku 1476, ta bowiem data znajduje się na tablicy erekcyjnej, wyobrażającej patronkę kościoła św. Małgorzatę trżymającą herb fundatora Wieniawę. Herby Wieniawa i kapituły krakowskiej mieszczą się na zwornikach sklepiennych w prezbiterium. Nadto obok tablicy fundacyjnej Długosza przypominają herby Wieniawa na sklepieniu prezbiterium, kruchty, nad portalem głównym oraz portalem wiodącym do kruchty ${ }^{24}$.

Jan Długosz przyczynił się walnie do odnowienia klasztoru klarysek w Krakowie. W roku 1455 spaliła się południowa część Krakowa. Dziejopis zanotował: ,...wszczął sję pożar w domu Tomasza płatnerza, na ów czas rajcy krakowskiego, obok kościoła św. Piotra [...]. Zgorzało przeszło sto domów na ulicach Grodzkiej i Kanonnej, przy tym cztery kościoły św. Piotra, Jędrzeja, Marcina i Marii Magdaleny, tudzież wspaniałe kollegium prawnicze. Dwa tylko domy kanonicze, jeden mistrza Mikołaja Spicinera kantora, a drugi Jana Długosza kanonika krakowskiego, z trudnością ocalały" ${ }^{25}$. Wkrótce po pożarze Długosz wraz z kanonikiem Janem Gosławskim z Bębelna przeprowadzili własnym sumptem restaurację spalonego klasztoru klarysek. W zamian za pomoc przy odnowieniu otrzymali od zakonnic w dożywocie wieś Baranów oraz dziesięcinę z wsi klasztornej Zadroże. Jaki był zakres robót, co wykonano, na to w aktualnym stanie badań nie można dać wyczerpującej odpowiedzi ${ }^{26}$.

Nie zrealizował Długosz fundacji kartuzów w Krakowie. Myśl sprowadzenia do stolicy kartuzów zrodziła się około połowy XV stulecia i po pierwszych niepowodzeniach $\mathrm{z}$ lat 1461-1464 zaczęła nabierać realnych kształtów w roku 1477 . W tymże roku, dnia 10 września król Kazimierz Jagiellończyk wystawił dokument fundacyjny dla kartuzów, potwierdzony dyplomem biskupa Jana Rzeszowskiego z 7 października 1477. Konwent dostał grunta we wsi Bawół na Kazimierzu. Podstawą ekonomiczną egzystencji kartuzów miały być dobra klasztoru norber-

24 Liber beneficicrum II, s. 58; S. Tomkowicz, Raciborowice, Kraków 1906, s. 9, 13, 25; tenże, Powiat krakowski, [w:] Teka grona konserwatorów Galicji Zachodniej, t. 2, Kraków 1906, s. 222, 228; Katalog zabytków sztuki w Polsce, t. 1, jw., s. $169 \mathrm{n}$.

25 Jana Dlugosza dziejów polskich..., jw., t. 5, s. 190.

26 W murach obecnego założenia nie stwierdzono śladów z czasów przebudowy dokonanej $\mathrm{z}$ inicjatywy Długosza. Por. również odnośny rękopis w Archiwum PP. Klarysek w Krakowie. 
tanek w Imbramowicach, który uległ likwidacji, a zakonnice przeniesiono jeszcze w 1 ćw. XV w. do Buska, zaś dobra klasztorne oddano pod opiekę zakonników reguły św. Norberta. Długosz nosił się z zamiarem przeniesienia Norbertanów z Imbramowic. Przyszły klasztor i kościól kartuzów zlokalizowano na parceli oddanej jeszcze przez Kazimierza Wielkiego Akademii Krakowskiej. Jak wiadomo uniwersytet nigdy nie wybudował w tym miejscu kolegiów, zatem grunt pod budowę był wolny. Jednak zamierzona fundacja napotkała na ostry sprzeciw ze strony władz miejskich Kazimierza. W roku 1478 proponowana lokalizacja nowego zakonu była przegrana. Jesienią tegoż roku Jan Długosz wracając z Węgier odwiedził austriacką kartuzję w Gaming. Stąd zabrał ze sobą do Polski przeora klasztoru w Gaming Zygmuta Phanzagla i brata Michała. Powróciwszy do Polski ponownie wszczął odpowiednie kroki w celu realizacji swego zamiaru. W połowie roku 1479 postanowił wreszcie zrealizować i doprowadzić do skutku fundację kartuzji. Zakupił zatem grunt znajdujący się pomiędzy wsiami Rakowice, Bieńczyce i Prądnikiem. Niestety i ta transakcja nie doszła znowu do skutku. Ostatecznie w roku 1480 upatrzył sobie Długosz podkrakowskie Bielany jako najodpowiedniejszy teren pod klasztor kartuzów. W owym czasie Bielany należały do panien norbertanek i rodziny Zarogowskich. Rozpoczął Długosz pertraktacje z Mikołajem Zarogowskim, właścicielem części Bielan. Na prośby dziejopisa Zarogowski ustąpił mu Bielany i spore tereny Chełmu, którego był właścicielem. Teraz Długosz mógł wreszcie przystąpić do budowy klasztoru kartuzów. Nakazał łamać łomy wapienia, ze znajdujących się na Bielanach skał wapiennych oraz obrabiać ciosy na projektowany kościół. Przyszła świątynia miała otrzymać wezwanie NMPanny i św. Stanisława, zaś w dokumentach dotyczących zamierzonej fundacji pojawia się nazwa „colles S. Stanislai”, którą Długosz ochrzcił wzgórze kartuzji ${ }^{27}$. Smierć Długosza.w roku 1480 przerwała zaczęte dzieło. Zamiar fundacji kartuzji nie został w Krakowie nigdy zrealizowany.

Dbał także Długosz o domy mieszkalne dla duchowieństwa w Krakowie, Wiślicy i Sandomierzu, czyli w miejscowościach, gdzie był kanonikiem. Wszystkie te fundacje są przejawem rzadko spotykanej troski o godziwe, warunki bytowania niższego kleru diecezjalnego.

Jako pierwszy powstał dom wikariuszy przy kolegiacie wiślickiej. Od czasów Długosza tamtejsi wikarzy mieszkali w dwóch drewnianych domach zbudowanych przez kasztelana krakowskiego Jana z Tarnowa. Domy te spaliły się i odtąd księża obsługujący kolegiatę zmuszeni zostali do zamieszkania u mieszczan wiślickich. $\mathrm{Z}$ wielu względów było to niewygodne, jak również powodowało szereg podejrzeń, czy nawet potwarzy. Kres temu stanowi rzeczy położył Długosz. W roku 1460 kupił place przy cmentarzu kościelnym i tamże wystawił zbudowany z cegły

27 Dokładnie omawia tę sprawę F. Sikora: O fundacji kartuskiej Jana Długo$s z a$, "Kwartalnik Historyczny" 80 (1973), s. 872-884. Por. też: S. Tomkowicz, Powiat krakowski, s. 6. 
i ciosu okazały dom na rzucie prostokąta, przeznaczony dla wikariuszy. U schyłku lipca roku 1466 roboty budowlane były daleko zaawansowane, lecz wiele prac przebiegało opieszale, o czym Długosz pisze w liście do nieznanego adresata. Mimo opóźnień budowlanych cieszył go jednak fakt, ,że nie zaprzestano robić”. Budynek mieszkalny dla wikariuszy wiślickich skończono $\mathrm{w}$ roku 1567. Budowa kosztowała sporo pieniędzy, bo aż 2000 grzywien ${ }^{28}$.

Chyba w tym samym czasie powstała przy wiślickiej kolegiacie wolnostojąca dzwonnica, którą także własnym sumptem postawił Jan Długosz. Założona na planie kwadratu jest budowlą czterokondygnacjową, podzieloną gzymsem na piętra, wykonaną z cegły i ciosu. Poniżej gzymsu koronującego zamyka ją fryz złożony z herbów Królestwa Polskiego, Wielkiego Księstwa Litewskiego, Wieniawa, Dębno, Poraj, Nałęcz, Rawicz, Grzymała, Ogończyk, Pilawa oraz hierogramu. Dokładna data wzniesienia dzwonnicy nie jest znana i można hipotetycznie przypuścić, że powstała niemal równocześnie $\mathrm{z}$ domem wikariuszy, zatem przed rokiem 1467. Nie wykluczone, że zbudowano ją około roku 1480 , bowiem Długosz nie wymienił jej w Liber beneficiorum, zatem za tą ostatnią datą przemawia ten fakt ${ }^{29}$.

Wyposażył także Długosz kolegiatę wiślicką w liczne paramenty liturgiczne. Biograf naszego kronikarza zapisał: „Vislicensi ecclesiae liberaliter erogavit purpureas vestes, auro illitas [...] Praeterea fuit auctor aurei calicis, qui maximüs in eadem est ecclesia, et inaurati vasculi, quo Eucharistia in solemni processione ad populum circumfertur" 30 . Niestety przedmioty tutaj wymienione $\mathrm{z}$ upływem lat przepadły. Wydaje się też prawdopodobne, że Długosz zainicjował fundację tablicy erekcyjnej z roku 1464 upamiętniającej fundatora kolegiaty króla Kazimierza Wielkiego. Płyta ta, wyobrażająca Kazimierza Wielkiego klęczącego $\mathrm{z}$ modelem kolegiaty przed Madonną, posiada szereg zbieżnych cech $\mathrm{z}$ tablicami fundacyjnymi umieszczonymi na budowlach wznoszonych kosztem Długosza ${ }^{31}$.

W roku 1471 biskup Jan Lutek z Brzezia wystawił na prośbę Jana Długosza dokument dla sandomierskich mansjonarzy. Wkrótce $\mathrm{z}$ fundacji dziejopisa wzniesiono dom mieszkalny przeznaczony dla mansjonarzy. $\mathrm{Z}$ czasu budowy przetrwały listy Długosza adresowane do mansjonarzy, dające doskonały pogląd na zakres i realizację fundacji. W listach z lat 1474-1478 wspomniany jest ',magister Johannes murator', któremu należy przypisać decydującą rolę przy budowie. Podobnie jak w Wiślicy, dwukondygnacjowy budynek założono na rzucie prostokąta, nakrywając

28 Liber beneficiorum I, s. 420 n.; Polkowski, jw., s. 327; Bobrzyński, Smolka, jw., s. 204; Wiśniewski, Historyczny opis, s. 448 n.; Łuszczkiewicz, Budowle Długosza, s. 77.

${ }_{29}$ Katalog zabytków sztuki w Polsce, t. 3, jw., z. 9, s. 101; Wiśniewski, Historyczny opis, s. 448; Smoleńska, jw., s. 172 n.

so Vita Joannis Dlugosch, jw., s. 39.

31 Katalog zabytków sztuki $w$ Polsce, t. 3, jw., z. 9, s. 97; Wiśniewski, Historyczny opis, s. 431. 
go strzelistym dwuspadowym dachem ze szczytami blendowymi od strony zachodniej i wschodniej. Dekorację rzeźbiarską tworzą herby Wieniawa i tablica erekcyjna zawierająca tylko herb Długosza i datę $1476{ }^{32}$.

Pozostałe domy dla duchowieństwa wzniósł Długosz w Krakowie. Nie zachował się do dzisiaj dom psałterzystów na Wawelu. U schyłku XIV stulecia królowa Jadwiga i Władysław Jagiełło utworzyli w katedrze krakowskiej kolegium psałterzystów. Królowa wzniosła dla nich dom, położony w zachodniej części wawelskiego wzgórza ${ }^{33}$. Budynek psałterii przetrwał w tym stanie do drugiej polowy wieku XV. Dnia 15 listopada 1474 roku Długosz zawarł w imieniu swoim psałterzystów kontrakt z muratorem krakowskim Marcinem o budowę nowej psałterii. Murator zobowiązał się, ,muros ex fundamentis deducere ex integritate ipsam domum usque ad superioritatem murorum perficere [...] ad festum sancti Michaelis proxime affuturum" "34. Zatem dom miał stanąć na jesień roku 1475 . Wymieniony w umowie Marcin identyfikowany jest z działającym w Krakowie Marcinem Proszko, znanym $\mathrm{z}$ wielu realizacji na terenie miasta ${ }^{35}$. Po jego śmierci prace przy psałterii kontynuował murator Jan, równolegle pracujący $\mathrm{w}$ Kłobucku ${ }^{36}$. Budowę ukończono w roku 1480 , ta bowiem data znajduje się na tablicy erekcyjnej wmurowanej w roku 1876 w ścianę południową domu Długosza przy ulicy Kanoniczej. Tablica wyobraża fundatora klęczącego przed tronującą Madonną oraz św. Jana Chrzciciela stojącego za Długoszem. Całość uzupełnia wytworny napis łaciński. Do wyglądu wawelskiej psałterii mamy doskonale zachowane materiały ikonograficzne. Dom stał w pobliżu baszty Sandomierskiej. Był to piętrowy budynek z cegły i ciosu wzniesiony na planie prostokąta, nakryty strzelistym dachem siodłowym. Zburzono go w roku $1856 \mathrm{w}$ ramach akcji urbanistycznego porządkowania Wawelu przez władze austriackie ${ }^{37}$.

Jan Długosz z tytułu piastowania godności kanonika kapituły krakowskiej otrzymał wraz z bratem rezydencję przy ulicy Kanoniczej i już od połowy XV stulecia zamieszkał w domu położonym u stóp Wawelu. Dom ten był u schyłku XIV wieku łaźnią królewską, ofiarowaną w roku 1390 Krystynowi z Ostrowa. W roku 1413 król Wałdysław Jagiełło zezwolił

32 J. Długosz, Operia omnia, t. 1, Cracoviae 1887, s. 633-637; Bobrzyński, Smolka, jw., s. 204; N. Pajzderski, Kościół św. Jakuba i dom Długosza w Sandomierzu, [w:] Sprawozdanie $i$ wydawnictwo Towarzystwa Opieki nad Zabytkami Sztuki i Kultury za rok 1906, Kraków 1907, s. 15-18; Z. Słonimski, Dom Długosza $w$ Sandomierzu. „Architekt” 10 (1909), s. 161 n.; Łuszczkiewicz, Budowle Dtugosza, s. 77; Smoleńska, jw., s. 166; Katalog zabytków sztuki w Polsce, t. 3, Warsząwa 1962 , z. 11 ; s. 63,65 .

83 Liber beneficiorum I, s. 270; S. Tomkowicz, Wawel. T. 1: Zabudowania Wawelu $i$ ich dzieje, [w:] Teka grona konserwatorów Galicji Zachodniej, t. 4, Kraków 1908, s. 96.

34 Cracovia artificum 1300-1500. Opr. J. Ptaśnik, Kraków 1917, s. 205 (nr 634).

85 T. Dobrowolski, jw., s. 126 n.

s6 Smoleńska, jw., s. 164-166.

${ }^{37}$ Polkowski, jw., s. 327, 330; K. Bąkowski, Dom Długosza, Kraków 1897, s. 10; Tomkowicz, Wawel, s. 11 n., 97; W. Łuszczkiewicz, Trzy epoki sztuki na zamku krakowskim, Kraków 1881, s. 46. 
Krystynowi z Ostrowa na zamianę tego domu z kapitułą. W rezultacie obustronnego porozumienia kapituła otrzymała dom przy ulicy Kanoniczej, zaś Krystyn - dziesięciny ze wsi Kamyk i Sławkowice. Uzyskana w ten sposób nieruchomość kapituła przeznaczyła na mieszkanie dla kanoników. W roku 1430 kanonicy Mikołaj Hińcza i Jan z Rudnicy przebudowali dawną łaźnię. W dwadzieścia lat potem dom stał się miejscem zamieszkania Jana Długosza, który od roku 1453 mieszkał w nim ze swoim bratem Janem. Niebawem bracia przystąpili do rozbudowy rezydencji. Już w roku 1454 dobudowali wysuniętą część południową i zachodnia z widokiem na zamek, katedrę i Wisłę, znacznie poszerzając tym samym powierzchnię domu. Podczas pamiętnego pożaru w roku 1455 dom ten szczęśliwie ocalał, o czym nie omieszkał wspomnieć Jan Długosz ${ }^{38}$. Tutaj wreszcie kronikarz dokonał pracowitego żywota. Z fundacji Długoszów został dobudowany do byłej łaźni królewskiej piętrowy dom, tworzący w rzucie literę „L”, w póżniejszych czasach wielokrotnie przebudowywany i w niczym nie przypominajacy siedziby obydwu braci oraz licznych fundacji Długosza w typie domów w Wiślicy i Sandomierzu ${ }^{39}$.

Przy tej okazji warto wspomnieć, że Długosz zakupił w roku 1451 od Piotra Trzewlińskiego sąsiedni dom, zwany Lisią Jamą (ulica Kanonicza 23). Po przeprowadzonej adaptacji przeznaczył go na archiwum konsystorskie ${ }^{40}$. Również z osobą Długosza wiąże się dom pod numerem 5 na ulicy Kanoniczej. W Liber beneficiorum kronikarz zanòtował: „domus duodecim ab acie in parte sinistra ex duobus areis collecta est [...], murata est peccuniis Sbignei sancte memoriae cardinalis et episcopi Crac. per Johannem Dlugosch [...] sui testamenti executorem" ${ }^{41}$. Notkę tę uzupełnił w Vitae episcoporum: ,huius etiam sumptibus post fata [Sbignei] in duabus areis capitularibus executor suus Johannes Dlugosch [...] nobilem fabricavit cocto latere in sinistra manu dưodecimam domum [...] in platea Canonicali" 42. Wewnątrz tej posesji są zachowane dwa późnogotyckie międzyokienne filary, a na jednym z nich widnieje herb Dębno odnoszący się do kardynała Zbigniewa Oleśnickiego (zm. 1455), którego ostatnią wolę realizował Jan Długosz. Prace przy budowie tego domu zaczęto najpewniej po roku $1455^{43}$.

Zinteresowania Długosza nie sprowadzały się jedynie do przedsięwzięć czysto budowlanych, lecz także do fundacji przedmiotów uświetniających

38 Liber beneficiorum I, s. 185; Jana Długosza dzijeów polskich..., jw., t. 5 , s. 190; I. Polkowski, Dom Jana Dtugosza, Kraków 1880, s. 3-7; K. Hoszowski, Domy $w$ Krakowie niegdyś braci Janów Dlugoszów, kanoników katedralnych krakowskich, Kraków 1882, s. 10.; Bąkowski, jw., s. 8 n.; Archiwum Kapituły Katedralnej Krakowskiej: Acta actorum capitularia, t. 1, k. 23.

${ }_{39}$ A. Swaryczewski, Badania architektoniczne obiektów przy ulicy Kanoniczej $w$ Krakowie, [w:] Zagadnienia badawcze $i$ projektowe zespotu ulicy Kanoniczej w Krakowie, Kraków 1971, s. 131 n.; Pieradzka, jw., s. 81-85.

40. Vita Joannis Dlugosch, jw., s. 38; I. Polkowski, Dom Jana Dtugosza, s. 11; K. Hoszkowski, jw., s. 39; K. Bąkowski, jw., s. 12; J. Kracik, Zasoby Archiwum Kurii Metropolitalnej w Krakowie. „Analecta Cracoviensia” 9 (1978), S. 487-488.

41 Liber beneficiorum I, s. 188.

42 J. Diugosz, Opera omnia, t. I, s. 428.

43 A. Swaryczewski, jw., s. 97. 
wnętrza kościołów. Dzieła te musiały stać na bardzo wysokim poziomie artystycznym. W roku 1460 zawarł Długosz umowę z mistrzem Jakubem z Sącza (pictor de Nova Sandecz). Artysta zobowiązał się namalować kopię francuskiej tkaniny wyobrażającej pasję Chrystusa na tle Jerozolimy. Przy tym kopia miała być ,piękniejszą pod względem dzieła i malowidła, niż jest namalowaną opona przysłana tutaj przez królową Francji" ${ }^{4}$.

Wszystkie budowle fundowane przez Długosza są bardzo zwartą grupa artystyczną, posiadającą analogiczne cechy formalne. Kronikarz budował gmachy trwałe, solidne i przede wszystkim funkcjonalne. Wznoszono je z cegły, używając do detali ciosów kamiennych. Charakterystyczną cechą jest sposób kształtowania ściany i otworów okiennych oraz drzwiowych. Budynki świeckie posiadają plan wydłużonego prostokąta, z reguły są dwukondygnacjowe, podpiwniczone, nakryte siodłowym dachem ze szczytami akcentowanymi blendami. Budowle sakralne przedstawiają znany na terenie Małopolski typ wiejskiego kościoła i cechuje je daleko posunięta skromność, połączona $\mathrm{z}$ redukcją programu architektonicznego. Kościoły budowane sumptem Długosza miały prostokątną, opiętą skarpami nawę oraz takież samo nieco mniejsze prezbiterium. Powtarzają typ budowli sakralnej ukształtowany w poł. XIV wieku. Przy skromności założeń architektonicznych na baczną uwagę zasługują kamienne detale. Nowym motywem dekoracyjnym, który pojawił się w architektonicznych fundacjach Długosza jest okazały wzbogacony formalnie portal typu schodkowego, znacznie różniący się od poprzednich portali tego typu, stosowanych często w architekturze Małopolski począwszy od początku XV w. ${ }^{45} \mathrm{~W}$ tradycyjnym portalu schodkowym z krzyżującymi się laskami pojawi się teraz nowy motyw zdobniczy: w węgarach stosuje się piramidki, a czasem zjawi się sznur okalający ostrołukowe zamknięcie wejścia. Elementem wspólnym łączącym kościelne i świeckie fundacje Długosza jest ułożona w romby zendrówkowa, ceglana dekoracja ścian oraz kamieniarka otworów okiennych i drzwiowych. Obok wspomnianych portali, okna w budowlach świeckich przynależą do typu okien prostokątnych, zamkniętych schodkowymi obramieniami ze skrzyżowanymi laskami. W budowlach kościelnych gzyms koronujący, wykonany $z$ formowanej cegły, podkreślony jest dodatkowo pasem cegieł ułożonych w jodełkę. Podobny pas podkreśla szczyty kościelne dekorowane zendrówką lub akcentowane płytkimi blendami. We wnętrzach kościelnych na zwornikach umieszczo-

44 Cracovia artificum, nr 523; E. Polak-Trajdos, Więzi artystyczne Polski ze Spiszem $i$ Stowacja od połowy XV do początków XVI wieku, Wrocław-Warszawa--Kraków 1970, s. 102.

45 Genezę tego typu portalu omawiają: Z. Bocheński, S. Swiszczowski, Zamek w Dębnie, [w:] Pamiętnik Związku Historyków Sztuki i Kultury, t. 1, Warszawa 1948, s. 50; J. Smoleńska, jw., s. 174 nn; Z. Swiechowski, Regiony w późnogotyckiej architekturze Polski, [w:] Późny gotyk, Warszawa 1965, s. 134. 
no herby Królestwa 'Polskiego, kardynała Zbigniewa Oleśnickiego oraz Wieniawę, nadto w zależności od lokalizacji świątyni herby miejscowego rycerstwa czy też kapituły krakowskiej. Najczęściej umieszczał Długosz rodzinną Wieniawę, w ten sposób upamiętniając dla współczesnych i potomności autorstwo swych fundacji.

Długosz nie traktował działalności fundacyjnej ex professo, lecz był świadom mecenasowskiego dzieła i pragnął, by pamięć o nim pozostała u 'potomnych. Budynki tak świeckie, jak i kościelne zawdzięczające swe powstanie Długoszowi opatrzone są płytami erekcyjnymi. Swiadczy to o pełnej świadomości fundatorskiej, a wniosek ten zdają się potwierdzać herby Wieniawa, umieszczone zazwyczaj na widocznym miejscu ${ }^{46}$.

Budowle powstałe w zasięgu mecenatu Jana Długosza nie są dziełem jednego warsztatu. Pierwsze $\mathrm{z}$ nich, jak kościoły w Chotlu Czerwonym i Odechowie różnią się detalem architektonicznym od późniejszych fundacji z lat 1470 - 1480. Te ostatnie są wyjątkowo jednolite pod względem konceprji przestrzennej, jak również stosowania detalu architektonicznego. Przypuszczalnie realizował je jeden warsztat. Sugestię tę potwierdza analiza formalna i zachowane przekazy źródłowe ${ }^{47}$. W źródłach dotyczących fundacji Długosza występuje dwóch mistrzów: Jan (mansjonaria w Sandomierzu) ${ }^{48}$ i Marcin murator, identyfikowany z Marcinem Proszko pracującym przy wawelskiej psałterii ${ }^{49}$. Przypomnieć trzeba, że Proszko psałterii nie ukończył, a po jego śmierci dzieło realizował mistrz Jan, działający równocześnie w Kłobucku. Działalność Marcina Proszko zamyka się w latach 1456-1476, zaś murator Jan notowany jest w źródłach w latach 1476-1480. Wzmianki archiwalne pozwalają ustalić autorstwo warsztatu budowlanego Marcina Proszko i Jana w odniesieniu do wawelskiej psałterii i kościoła kanoników laterańskich w Kłobucku. Ponadto w zachowanym materiale źródłowym występują jeszcze dwaj cieśle Karcz (Sandomierz) i Jan (psałteria), nadto zarządzający budową w Sandomierzu Mikołaj Lorincz i Stanisław Łukawski, zaś w Kłobucku Andrzej ze Mstowa ${ }^{50}$. Na podstawie analizy stylistycznej można sądzić, że Marcin Proszko i Jan pracowali także przy budowie kościołów w Raciborowicach; Szczepanowie oraz przy wieży kolegiaty $\mathrm{w}$ Wiślicy ${ }^{51}$. Warsztat pracujący dla Długosza realizował również inne budowle. Wiele cech zbieżnych z fundacjami budowlanymi naszego dziejopisa odnajdujemy w zamku w Dębnie koło Brzeska (1470-1480) oraz w kościele parafialnym tamże. Podobne motywy kamieniarskie występują w kolegiacie św. Małgorzaty i domu kanoniczym w Nowym Sączu, nadto w prezbiterium fary bieckiej

46 S. K. Kuczyński, jw., s. 226-227. O problemie mecenatu w średniowieczu pisze A. M. Olszewski: Niektóre zagadnienia stylu międzynarodowego $w$ Polsce, [w:] Sztuka i ideologia XV wieku, jw., s. 272.

47 J. Smoleńska, jw., s. 163; A. Miłobędzki, Późnogotyckie typy sakralne $w$ architekturze ziem polskich, [w:] Pózny gotyk, jw., s. $92 \mathrm{nn}$.

48 J. Smoleńska, jw., s. 163, 166-169, 172.

49 Tamże, s. 164-166; Wypisy źódłowe do dziejów Wawelu, jw., nr 86.

se J. Długosz, Opera omnia, t. 1, s. 633, 635; J. Smoleńska, jw., s. 170.

s1 J. Smoleńska. jw., s. 171. 
(ok. 1480) i kościołach w Bobowej i Szańcu (1499) ${ }^{52}$. W stworzonych przez ten warsztat budowlach stosowano wypracowane formy dekoracyjne, zastosowane w kamieniarce katedry św. Wita w Pradze. Warsztat fundacji Długosza działał także w ramach konwencji tradycyjnej kamieniarki parlerowskiej, wypracowanej jeszcze w 2. połowie XIV wieku.

* $\quad * \quad *$

Jan Długosz jest wyjątkową osobowością schyłku polsk ego średniowiecza. Ten wychowawca synów Kazimierza Jagiellóńczyka, wytrawny dyplomata, autor dziejów Polski, dzieła nie mającego analog:i w europejskim pisarstwie, okazał się także niepoślednim mecenasem. Rozumiał i doceniał wartość sztuki. Dał temu niejeden raz wyraz na kartach swych dzieł. Nieraz podkreślał piękno i harmonię współczesnych i wcześniejszych budowli. Mimo podróży do Italii, pozostał nadal nieodrodnym dzieckiem średniowiecza. Wszystkie jego funkcje mają z gruntu gotycki charakter. Budował zawsze $\mathrm{z}$ myślą o innych, zwracając baczną uwagę na funkcjonalność budynku, nie zaniedbując przy tym artystyeznej strony budowli. Podziw budzi ilość dzieł, tych zrealizowanych i zi mierzonych, oraz instytucji, którym początek dał Długosz. Zwłaszcza funciacjom artystycznym - co wynika z listów - oddawał Długosz wiele serca, mnóstwo starań i zapobiegliwości, dbając równocześnie o najdrobniejsze szczegóły. Staranną opieką otoczył fundacje na rzecz Kościoła, pozostawiając po sobie na terenie rozległej w owym czasie diecezji krakowskiej dzieła stanowiące pomnik jego doczesnej chwały.

W artykule zastosowano następujące skróty:

Liber beneficiorum - J. Długosz, Liber beneficiorum dioecesis Cracoviensis Ed. Ż. Pauli. Vol. I-III, Cracoviae 1863-1864.

PAN - Biblioteka Oddziału krakowskiego Polskiej Akademii Nauk. PSB - Polski Słownik Biograficzny.

52 Omawia je J. Smoleńska (jw., s. 175-176). Bocheński i Swiszc zowski (jw:, s. 45-46, 49) łączą architekture $\mathrm{z}$ warsztatem Marcina Proszko, budowr.iczego psałterii. Problem fundacji Długosza ostatnio poruszyła A. Buczek, Mecenat artystyczny Jana Diugosza w dziedzinie architektury, (w:) Dlugossiana, Warszawa 1980, s. 108 $-138$. 
LES FONDATIONES DE JAN DEUGOSZ FOUR L'EGLISE CATHOLIQUE

Rés um é

Jan Dlugosz, personnage exceptionnel dans l'histoire du Moyen Age polonais fut le précepteur des fils du roi,-l'auteur de ,l'Histoire de Pologne" et à la fois un remarquable mécène des arts dont la valeur il appréciait et comprenait profondement. Son activité de fondateur pour l'Eglise n'a pas d'analogie dan: la culture polonaise du XVe siècle.

Il fonda des églises construites en pierres à Chotel Czerwony (1450), Kłobuck, Odechów (1459-1460), Szczepanów (1470), Raciborowice (1476) et à Skałka à Cracovie.

Il éleva des maisons pour le clergé de Cracovie, de Wiślica et de Sandomierz. En outre il dota, bien nombre d'églises des habits et des récipiants liturgiques de grande valeur. A notre époque on ne garde qu'une chasuble à l'église de Kłobuck. Toutes ces constructions fondées par Jan Długosz constituent un groupe artistique bien uni. Aux travaux de construction participèrent les architectes cracoviens Marcin Proszko et le maitre Jan. 